the deflection was the greatest on connecting the terminals with the galvanometer.

If the fact already pointed out be taken into account that with a constant battery-potential, the difference of potential between the terminals of a vacuum-tube varies, in the same gas, according to the degree of exhaustion, it follows that as soon as a discharge takes place, the potential of the terminals will be lowered. One would therefore expect to find what the before-cited experiments indicated, namely, that the static charge of the terminals would be greater when no discharge takes place than after it has occurred, notwithstanding that a larger number of cells may have been employed in the latter case than in the former, for the authors have shown (Phil. Trans., vol. clxxi. p. 67) that a tube-potential may be only 430 cells, although the battery connected with its terminals is I I,, 00 cells.

The authors believe, therefore, that the experiments point conclusively to the deduction that the current obtained from the terminals of a vacuum tube, after having been disconnected from the battery, is solely due to a static charge and not to a chemical polarisation.

An experiment was made with the apparatus arranged as in Fig. 4, a tangent galvanometer being inserted in the

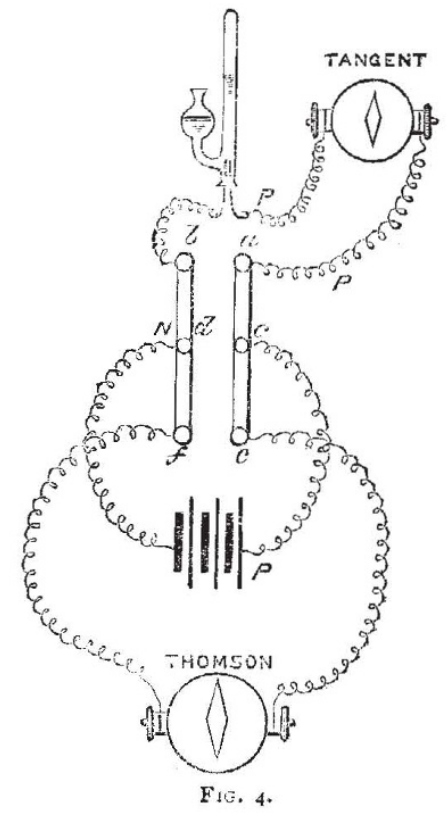

circuit between the battery and the voltameter, the $\frac{1}{99} 9$ shunt being used with the Thomson galvanometer.

\begin{tabular}{|c|c|c|c|c|c|c|c|}
\hline \multicolumn{2}{|c|}{ No. of cells. } & \multirow[t]{2}{*}{$\begin{array}{l}\text { Current } \\
\text { indicated by } \\
\text { the tangent } \\
\text { galvanometer. } \\
\text { W. } \\
0.00000\end{array}$} & \multicolumn{4}{|c|}{$\begin{array}{c}\text { Defiection of Thom- } \\
\text { son galvanometer, } \\
\text { with shunt gis, } \\
\text { on pressing down } \\
e \text { and } f \text {. }\end{array}$} & \multirow{3}{*}{$\begin{array}{l}\text { Divisions. } \\
218,930 \\
761,380\end{array}$} \\
\hline $\mathbf{I}$ & $\cdots$ & & $\ldots$ & 220 & $953^{1}$ & $\cdots$ & \\
\hline 2 & $\cdots$ & 0.00415 & $\ldots$ & 765 & o & & \\
\hline 3 & $\cdots$ & 0.03463 & & 984 & & & 978,820 \\
\hline IO & $\ldots$ & 0.14660 & ... & 990 & & & 985,150 \\
\hline
\end{tabular}

On keeping down the keys $e$ and $f$ after the voltameter had been connected with three cells, the deflection, which at first was 984 divisions, fell in-

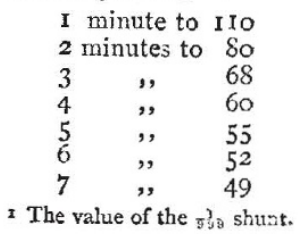

so that it was evident that a current was kept up by the voltametcr for a considerable time after the battery had been disconnected.

In order to render evident the direction of the current of polarisation of the voltameter the apparatus was arranged as in Fig. 5, that is, the Thomson galvanometer, with $\frac{1}{9} \overline{9}$ shunt, was inserted in the circuit between the battery and the voltameter. An adjustable shunt was fixed between $a$ and $b$ to permit the greater part of the current to pass through it. A plate of metal, $s s$, was provided to slip under $e$ and $f$ to short circuit the return current through the galvanometer. The shunt which was found just sufficient to carry the major part of the current, and yet permit sufficient to traverse the voltameter to produce a just visible evolution of gas, was I $3 \mathrm{ohms}$.

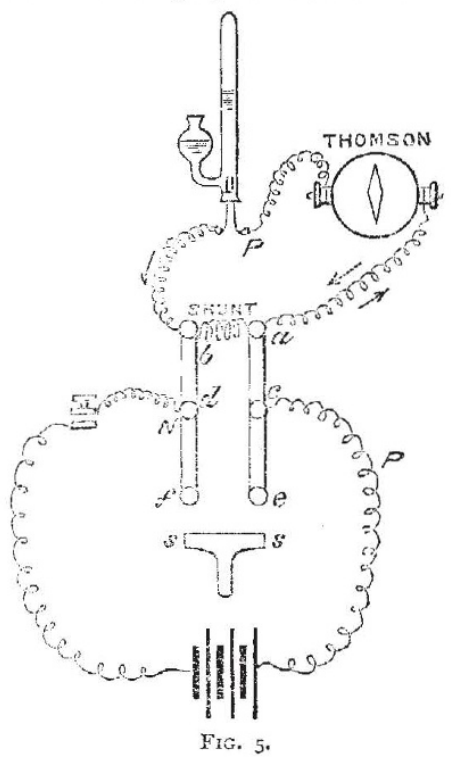

On connecting the battery, the current was in the direction of the lower arrow, and the deviation 133 divisions say to the left ; on pressing down the keys on to the metal slip placed under them to short circuit the current, after the battery had been disconnected, the return current was in the reverse direction, as shown by the upper dotted arrow, the deviation being 425 divisions to the right. Even without pressing down the keys on to the metal slip nearly the same deviation was obtained on disconnecting battery for the return current then traversed the shunt from $a$ to $b$.

On substituting either the bell-jar, with disk terminals, or the tube 199 for the voltameter, the deflection of the return static charge was in the same direction as the return current from the voltameter, so that, as was before stated, no inference can be drawn from the direction of the current as to its being produced by polarisation or a static charge. The authors conclude by saying :-We think, however, that we have shown that the cffect in the case of a vacuum-tube is due to a static charge, and not to a polarisation of the terminals. We rest our opinion mainly on the fact that a greater deflection is produced, when the potential has not been lessened by a discharge through the tube, than that which occurs after the discharge has taken place, which, it had been surmised, might possibly produce a chemical polarisation.

\section{THE LATE M. GAUGAIN}

SCIENCE has to deplore the loss of an industrious but unobtrusive worker in the person of Jean-Mothée Gaugain, who died at the village of St. Martin d'Estreaux, 
near Bayeux, on the 3 rst of May, r88o. His name is honourably associated with experimental researches in a good many of the less-frequented bye-paths of electrical science. Living in a time which may well be regarded as the transition period, during which electricity has passed from the stage of a phenomenal and experimental science to one of exact mathematical relations, some of Gaugain's investigations are already superseded by the later and more comprehensive researches of a younger generation. Yet he has done good work, which will live to carry down his name along with that of Peltier, of Pouillet, and of Becquerel, and with the still greater names of Arago and of Ampère.

His earliest contribution to science of which we are aware was a memoir published in 1853 , under the title "Note sur les Signes Electriques attribuées au Mo'ıvement de la Chaleur," and in the same year he brought out his tangent galvanometer. The essential point of this instrument consisted in employing as a coil several turns of wire of increasing diameter arranged about a conical surface, at whose imaginary apex was placed the small magnetic needle, each of the coils thus subtending the same solid angle at this point. This arrangement, to which Gaugain was experimentally led, was in some points virtually anticipated by the tangent galvanometer of Helmholtz, in which, however, a symmetrical arrangement was employed. In the same year Gaugain announced the discovery that continuous currents of electricity could be produced by the continuous friction of two dissimilar metals upon one another. The next two years saw him employed in investigating the electricity produced by evaporation and by combustion. In 1856 he produced his double-condenser electroscope, designed, like the condensing-electroscope of Volta, for the investigation of the electrification due to contact of dissimilar substances. At the same time he published some observations on the behaviour of amalgams of sundry metals, and showed that in a voltaic pair the amalgam of zinc was more electropositive than zinc itself, while the amalgam of cadmium was on the other hand, more electro-negative than the pure metal. From 1856 to I859 Gaugain was occupied with important inquiries on pyroelectricity, and he succeeded in establishing sundry laws, with respect to the electricity of the tourmaline in particular, which had escaped previous observers. The results he arrived at were publishedin the Annales de Chimie et de Physique, and comprised a number of curious and unexpected results. The tourmaline, which at ordinary temperatures is a bad conductor, even for high-tension electricity, begins to conduct at $400^{\circ}$ or $500^{\circ} \mathrm{C}$., and on cooling is still found to conduct; but if washed in water and dried carefully it once more insulates. All tourmalines are not equally active, those of Brazil, green or blue in colour, being the most electrical. In order to obtain a measure of the amount of electricity furnished by a tourmaline whose poles were united by a metallic circuit, he devised a discharging gold-leaf electroscope, and by means of this instrument showed that a number of tourmalines united by their similar poles gave quantities of electricity proportional to their number, while if united in single series they gave no more than a single long one, thus behaving like batteries of great electromotive force and of almost infinite internal resistance. The quantities of electricity furnished by tourmalines of equal lengths but of different thickness while passing through equal ranges of temperature he found to be proportional to the cross-sections of the crystals, again agreeing with the law of $\mathrm{Ohm}$ as applied to batteries of very high internal resistance. Gaugain also showed the quantity of electricity thus flowing through the tourmaline in one direction during a rise of temperature to be equal to that flowing in the reverse direction during a corresponding fall. The year following the discharging electroscope was usefully employed in verifying Ohm's law as applied to other bad conductors. Volta's contact theory occupied Gaugain at several periods of his career, and he established amongst other interesting results that there is a difference of potential between a piece of platinum which has been dipped into acid, and one which has been dipped into alkali, even though both have been subsequently washed. Gaugain also conducted a number of careful researches on specific inductive capacity, on the capacity of cables, on the residual charge of condensers, and on what he termed the variable electric state of a condenser communicating with the soil by a bad conductor, in which, when discharged by disruptive sparks or by the discharging electroscope, the timeintervals of the discharges were found to form a geometric progression. His extended observations on condensers of spherical, cylindrical, and flat forms were communicated to the Académie des Sciences in three special notes. In later years Gaugain devoted himself to the examination of the effects of heat upon the magnetism of steel tubes and bars, and found the remarkable result that a bar magnetised powerfully while hot may when cooled exhibit a reversed polarity, and vice versa $\hat{a}$; also that the magnetisation by a strong current penetrates deeper than that due to a weaker current. He also brought to light sundry analogies between the behaviour of magnets under magnetic force, and of matter generally under mechanical forces.

Born in Normandy in 18 ro, he entered the École Polytechnique at about the age of eighteen, and afterwards attended the École d'Artillerie at Metz, after which he adopted metallurgy as his profession. Gaugain worked during the closing years of his life in isolation and in straitened circumstances, assisted by his only daughter, who devoted herself to him. His researches, though several times rewarded with academic recognition, were not in themselves productive of gain ; and the prix Gegner, an annual grant of 4,000 francs, given dun savant pauvre afin de laider dans ses recherches, awarded to him for five years past, was a welcome amelioration of his position in a time of failing health and during the painful illness to which he succumbed at the age of seventy years.

S. P. T

\section{A CHAPTER IN THE HISTORY OF THE CONIFERAE}

$\mathrm{T}$ working out the Eocene coniferæ, in continuance of the monograph which the Palæontographical Society are kindly publishing and illustrating in a sumptuous manner, some reflections upon the past history of the more prominent Eocene genera, such as Araucaria, Podocarpus, Dammara, Sequoia, \&c., have occurred to me, which, although being perhaps outside the scope of the Palæontographical Society's work, may not be uninteresting to the general readers of NATURE. I have therefore tentatively brought forward the present chapter on Araucarias without yet having any definite intention of putting together my notes upon the other genera, in the present form.

Araucar $i a,{ }^{1}$ Jussieu.- The earliest traces of distinctly coniferous wood known, those from the Carboniferous, were for many years thought to belong exclusively to the Araucarian type. This supposed prototype became, according to Schimper, modified in successive ages, and he endeavours to trace these modifications through the extinct genera Walchia, Ullmannia, Araucarites, Voltzia, Ptycholepis, Pachyphyllum, and Cunninghamites. Lesquereux, however, carries the actual genus Araucaria to as far back as the Trias, and unmistakable cones of both sections of the genus have been described by Carruthers from the Stonesfield, Yorkshire, and Somersetshire oolites; fossil forms agreeing closely with these have been also found in the Jurassic of India. It is not

x From Araucanos, a people of Chili, in which country A. imbricata abounds, and furnishes the principal food of the Indians. 